\title{
KARAKTERISTIK MUTU HEDONIK KERUPUK UBI JALAR DAN RUMPUT LAUT (kappaphycus alvarezii) YANG DIFORTIFIKASI DENGAN IKAN LAYANG (Decapterus Russelli)
}

\author{
Henra*1; Nikmawatisusanti Yusuf1; Asri Silvana Naiu1 \\ 1 Jurusan Teknologi Hasil Perikanan, Fakultas Perikanan dan IImu Kelautan, Universitas Negeri Gorontalo, \\ J..Jenderal Sudirman No.06, Kota Gorontalo 96128, Gorontalo, Indonesia \\ *Korespondensi: henraperikanan12@gmail.com \\ (Diterima 06-04-2020 / Di publikasi 06-04-2002)
}

\begin{abstract}
ABSTRAK
Penelitian ini bertujuan untuk menganalisis pengaruh fortifikasi daging ikan layang terhadap karakteristik mutu hedonik kerupuk ubi jalar. Faktor perlakuan penelitian adalah konsentrasi daging ikan layang yang berbeda yang formula kerupuk terdiri dari 30\%, 50\% dan $70 \%$. Parameter organoleptik mutu hedonik meliputi kenampakan, aroma, rasa dan tekstur. Penelitian ini di analisis menggunakan Kruskal Wallis menunjukkan bahwa fortifikasi daging ikan layang yang berbeda memberikan pengaruh nyata. Hasil uji Bayes dari mutu hedonik menunjukkan bahwa produk terpilih adalah formula $\mathrm{C}$ dengan komposisi daging ikan $70 \%$, rumput laut $75 \%$ dan tepung ubi jalar $100 \%$. Hasil mutu hedonik produk terpilih memiliki kriteria kenampakan utuh, rapi, bersih, kurang homogen, ketebalan tidak rata, warna coklat, rasa ikan cukup kuat, aroma ikan cukup kuat dan tekstur kering, agak getas. Fortifikasi daging ikan layang dapat meningkatkan protein, lemak, air, aroma dan rasa, namun menurunkan nilai kenampakan, tekstur dan karbohidrat.
\end{abstract}

Kata kunci : Fortifikasi, kerupuk, ikan layang (Decapterus ruselli), mutu hedonik

\section{ABSTRACT}

This study aims to analyze the effect of fortification of flying fish meat on the hedonic quality characteristics of sweet potato crackers. The research treatment factor was the concentration of different flying fish meat with a cracker formula consisting of $30 \%, 50 \%$ and $70 \%$. Organoleptic parameters of hedonic quality include appearance, aroma, taste and texture. This research analyzed using Kruskal Wallis shows that the fortification of different flying fish meat has a real influence. Bayes test results from hedonic quality showed that the selected product was formula $\mathrm{C}$ with $70 \%$ fish meat composition, $75 \%$ seaweed and $100 \%$ sweet potato flour. The hedonic quality results of selected products have the criteria for appearance intact, neat, clean, less homogeneous, uneven thickness, brown color, fish taste is strong enough, fish aroma is strong enough and texture is dry, somewhat brittle. Fortification of flying fish meat can increase protein, fat, water, aroma and taste, but decrease the appearance value, texture and carbohydrate.

Keywords: Decapterus ruselli; hedonic quality, fortification, crackers. 
Meningkatnya jumlah penduduk Indonesia setiap tahun menyebabkan kebutuhan pangan di Indonesia semakin bertambah. Saat ini, usaha penganekaragaman pangan (ketahanan pangan) sangat diperlukan sebagai usaha untuk mengatasi masalah ketergantungan pada satu produk pangan pokok saja. Misalnya dengan mengolah bahan pangan seperti umbiumbian, buah-buahan, sayur mayur, hasil laut, ataupun bahan dasar lainnya menjadi berbagai bentuk makanan ataupun minuman yang mempunyai rasa khas dan tahan lama untuk disimpan. Salah satu penggunaan sumber bahan pangan yang beraneka ragam serta memiliki nilai gizi yaitu dengan memanfaatkan ikan dan rumput laut serta ubi jalar dalam pembuatan kerupuk.

Diversifikasi pengolahan ikan dan rumput laut dapat dilakukan dengan cara membuat kerupuk ikan yang ditambahkan rumput laut. Salah satu rumput laut yang dapat digunakan dan sering dimanfaatkan dalam produk olahan yaitu rumput laut Kappaphycus alvarezii. $K$ alvarezii merupakan salah satu jenis rumput laut penghasil karaginan, utamanya dari jenis kappa karaginan. Rumput laut diketahui sebagai sumber serat pangan sebesar $78,94 \%$ dan vitamin A (beta karoten), B1, B2, B6, B12, C dan niacin, serta mineral yang penting, seperti kalsium dan zat besi (Astawan $d k k$, 2004). Winarno (1990), menerangkan bahwa penggunaan tepung karagenan biasanya dilakukan pada konsentrasi $0,005-3 \%$ atau tergantung pada produk yang ingin diproduksi. Penggunaan rumput laut $K$. Alvarezii dapat menyebabkan tekstur kerupuk menjadi renyah serta membuat kerupuk menjadi mengembang, karena rumput laut $K$. Alvarezii mengandung karagenan sehingga sangat mendukung sebagai bahan pembuat kerupuk. Menurut Winarno (1996) dalam Yulaningsih (2005), salah satu fungsinya yaitu mampu memperbaiki tekstur dan kerenyahan produk, serta dapat meningkatkan daya mengikat air.

Berdasarkan hasil penelitian Kasim (2016), bahwa penambahan rumput sebanyak $75 \mathrm{gr}$ pada pembuatan kerupuk ubi jalardapat memberikan tekstur yang baik dibandingkan penambahan rumput laut $50 \mathrm{gr}$ dan $100 \mathrm{gr}$. Fortifikasi rumput laut pada perlakuan $100 \mathrm{gr}$ menyebabkan tekstur kerupuk berbahan dasar ubi jalar menurun, hal tersebut diakibatkan oleh tingginya jumlah karagenan pada bahan yang ditandai dengan tingginya jumlah bubur rumput laut yang difortifikasi pada formulasi $100 \mathrm{gr}$, sehingga semakin banyak air yang terperangkap dalam adonan bahan kerupuk dan menyebabkan tekstur kerupuk sukar untuk mengembang.

Ubi jalar cukup potensial sebagai bahan baku industri karena kuantitasnya yang melimpah serta mudah dibudidayakan. Proses pembuatan tepungnya dapat dilakukan oleh industri rumah tangga. Oleh karena itu pemanfaatan ubi jalar sebagai bahan baku industri perlu dimasyarakatkan dan 
dikembangkan. Menurut Herudiyanto dkk (2008) dalam Ginting (2010), ubi jalar ini sangat potensial sebagai bahan baku produk-produk pangan berbasis tepung dan mampu bersaing dari segi kualitas produk yang dihasikan. Dalam penelitian ini digunakan ubi yang memiliki daging ubi warna putih. Menurut Irfansyah (2001), ubi jalar merupakan sumber karbohidrat, vitamin, dan mineral yang cukup tinggi dibandingkan dengan ubi kayu yang merupakan bahan pembuatan tepung tapioka, ubi jalar memiliki kandungan vitamin $\mathrm{A}$ dan $\mathrm{C}$, serta energi yang lebih tinggi.

Berdasarkan penelitian yang dilakukan oleh Kasim (2016), kerupuk ubi jalar yang difortifikasi dengan bubur rumput laut sebanyak $50 \mathrm{gr}, 75 \mathrm{gr}$ dan $100 \mathrm{gr}$ menghasilkan kadar air yaitu berkisar antara 7,12-7,73\%, kadar abu 3,89-3,97 \%, kadar lemak 15,92-22,90\%, protein 3,88-4,25\%, serat kasar 4,91-5,41\% dan karbohidrat 61,54-68,82 \%. Kadar protein yang dihasilkan belum memenuhi persyaratan protein kerupuk berdasarkan (SNI: 01-43071996).

Berdasarkan data Dinas Perikanan dan Kelautan Provinsi Gorontalo produksi ikan layang segar dari tahun 2010-2012 mengalami peningkatan rata-rata sebesar $3 \%$, namun pada tahun 2013 mengalami penurunan sebesar 16\% dan meningkat kembali pada tahun 2014 sebesar $24 \%$, hal tersebut menunjukan bahwa ikan layang (Decapterus sp.) tersedia dalam jumlah yang cukup banyak sehingga dapat dimanfaatkan sebagai bahan baku produk pangan (DPK Provinsi Gorontalo, 2014). Selain itu harga jual ikan layang masih relatif murah dan penggunaannya masih terbatas umumnya hanya sebagai ikan konsumsi seperti digoreng sehingga perlu upaya diversifikasi hasil olahan perikanan lainnya.

\section{METODE PENELITIAN}

\section{Waktu dan Tempat Penelitian}

Penelitian ini akan dilaksanakan pada bulan Maret sampai dengan Mei tahun 2019 di Kota Gorontalo. Pengujian organoleptik bertempat di Laboratorium Bioteknologi dan Karakteristik Hasil Perikanan Fakultas Perikanan dan IImu Kelautan Universitas Negeri Gorontalo.Pengujian kimiawi sampel dilakukan di Pusat Penelitian Sumberdaya Hayati dan Bioteknologi LPPM Jl. Kamper Kampus IPB Darmaga Bogor.

\section{Alat dan Bahan untuk Pembuatan Tepung dan Kerupuk}

Alat yang digunakan dalam pembuatan tepung dan kerupukyaitu oven, timbangan analitik, pisau, wadah, sendok, talenan, kompor, alat pengering.Sedangkan alat yang digunakan dalam proses pembuatan tepung adalah stopwatch, oven, terrmometer. Bahan yang akan digunakan dalam pembuatan tepung adalah ubi jalar. Bahan yang akan digunakan adalah ikan layang, rumput laut, tepung ubi jalar, bawang putih, gula, garam, putih telur dan air.

\section{Prosedur Penelitian}


1. Proses Pembuatan Tepung Ubi Jalar (Kasim, 2017).

Langkah awal yang dilakukan yaitu ubi jalar dikupas untuk memisahkan umbi dari kulitnya kemudian dicuci bersih menggunakan air mengalir, lalu daging ubi jalar diiris tipis-tipis kemudian direndam dalam larutan garam 0,2\% (2 gr garam dilarutkan dalam $1000 \mathrm{ml}$ air)selama 15 menit dan ditiriskan. Ubi jalar yang telah diiris disusun dalam wadah aluminium dan dimasukkan ke dalam oven untuk dikeringkan. Pengeringan menggunakan metode oven dengan suhu $70^{\circ} \mathrm{C}$ selama 9 jam.Ubi jalar yang telah dikeringkan, dihaluskan dengan menggunakan mesin penggiling, kemudian diayak dengan menggunakan ayakansehingga diperoleh tepung ubi jalar yang halus dan kering.

2. Proses Pembuatan Bubur Rumput Laut (Pakaya, 2014)

Pembuatan bubur rumput laut diawali dengan perendamanrumput laut dengan air bersih. Perendaman ini dilakukan karena rumput laut yang akan digunakan adalah rumput laut kering $K$. alvarezii. Perendaman dilakukan selama tiga hari dan dilakukan pergantian air rendaman setiap 12 jam. Perbandingan air rendaman yang digunakan untuk merendam rumput laut yaitu $4: 1$.

\section{Proses pembuatan kerupuk}

Proses pembuatan kerupuk mengacu pada Kasim (2017) yang telah dimodifikasi. Percobaan diawali dengan menyiapkan semua

http://ejurnal.ung.ac.id/index.php/jfpj/issue/archive bahan yang digunakan dan menimbang bahanbahan yang diperlukan sesuai dengan ukuran. Pada percobaan pertama, lumatan daging ikan yang digunakan yaitu $25 \mathrm{gr}$, bubur rumput laut $75 \mathrm{gr}$ dan tepung ubi jalar $100 \mathrm{gr}$, selanjutnya bawang putih, garam, gula, putih telur dihomogenkan kemudian ditambahkan sedikit demi sedikit lumatan daging ikan, bubur rumput laut dan tepung ubi jalar sesuai jumlahnya masing-masing kemudian dihomogenkan dan ditambahkan air sebanyak $20 \mathrm{ml}$. Selanjutnya adonan dimasukkan ke dalam plastik (pencetakan) dan dikukus selama 1 jam pada suhu $100^{\circ} \mathrm{C}$, setelah dikukus lalu didinginkan pada suhu ruang selama 1 jam, kemudian dicetak dengan cara diiris tipis-tipis. Selanjutnya dikeringkan selama 4 jam (menggunakan alat pengering mekanik pada suhu $60-65^{\circ} \mathrm{C}$ ). Kerupuk yang dihasilkan pada percobaan pertama memiliki kenampakan utuh, rapi, bersih, homogen ketebalan tidak rata, warna coklat, aroma ikan tidak ada, rasa ikan tidak ada, tekstur kering, getas. Berdasarkan hasil percobaan pertama, maka dilakukan percobaan kedua dengan menggunakan daging ikan 50 gr. Kerupuk yang dihasilkan memiliki kenampakan utuh, rapi, bersih, kurang homogen, ketebalan kurang rata, warna coklat, aroma ikan kurang kuat, rasa ikan sedikit serta memiliki tektsur kering getas.

Formula kerupuk ikan pada penelitian utama menggunakan ikan layang dengan konsentrasi $0 \%, 30 \%, 50 \%$ dan $70 \%$, dan 
dilakukan uji organoleptik mutu hedonik, proksimat dan uji tekstur.

\section{HASIL DAN PEMBAHASAN}

\section{Mutu Hedonik Kerupuk yang Difortifikasi dengan Rumput Laut}

\section{Tekstur}

Histogram tekstur kerupuk fortifikasi daging ikan layang dapat dilihat pada Gambar 1.

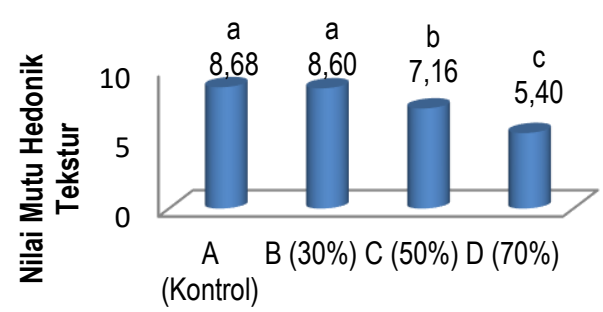

Gambar 1. Histogram tekstur kerupuk. Huruf yang sama pada histogram menunjukkan hasil yang tidak berbeda nyata dan sebaliknya

Gambar 1 menunjukkan nilai organoleptik mutu hedonik tekstur kerupuk berada pada kisaran 5,40 - 8.68. Nilai mutu hedonik tertinggi terdapat pada formula kontrol (tanpa fortifikasi daging ikan) yaitu 8.68 dengan kriteria kering, sangat getas. Sedangkan nilai organoleptik mutu hedonik terendah terdapat pada formula D (fortifikasi daging ikan 70\%) yaitu 5,40 dengan kriteria kering, agak getas.

Hasil uji Krukal wallis menunjukkan bahwa penambahan daging ikan layang pada kerupuk berbahan ubi jalar dan rumput laut memberikan pengaruh nyata pada tekstur produk (Lampiran 5). Hasil uji Duncan diperoleh bahwa formula $A$ dan formula B tidak berbeda nyata namun berbeda nyata dengan formula $\mathrm{C}$ dan formula D. Sedangkan formula C dan D berbeda nyata.Semakin tinggi fortifikasi daging ikan layang, tekstur kerupuk semakin menurun hal ini diduga karena kadar protein yang terdapat pada kerupuk semakin meningkat dan membuat tekstur menjadi kurang renyah.

\section{Aroma}

Histogram aroma kerupuk dapat dilihat pada Gambar 2.

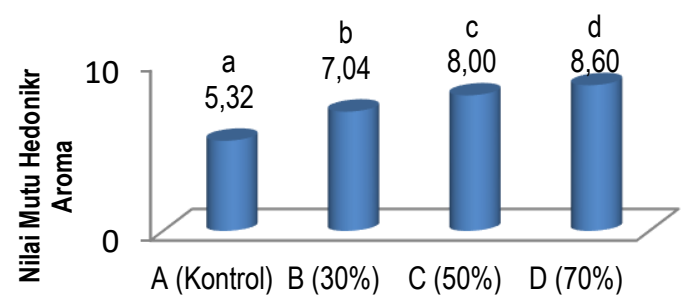

Gambar 2. Histogram aroma kerupuk. Huruf yang sama pada histogram menunjukkan hasil yang tidak berbeda nyata dan sebaliknya

Gambar 2 menunjukkan nilai organoleptik mutu hedonik aroma kerupukberada pada kisaran $5.32-8.60$. Nilai mutu hedonik aroma tertinggi terdapat pada formula $D$ (fortifikasi daging ikan $70 \%$ ) yaitu 8.60 dengan kriteria ikan cukup kuat. Sedangkan nilai mutu hedonik terendah terdapat pada formula A (tanpa fortifikasi daging ikan) yaitu 5.32 dengan kriteria aroma ikan tidak ada. Kerupukformula B memiliki nilai mutu hedonik 7.04 dengan kriteria aroma ikan sedikit, serta formula $C$ memiliki nilai mutu hedonik 8 dengan kriteria aromaikan kurang kuat.

Hasil uji Krukal wallis menunjukkan bahwa penambahan daging ikan layang pada kerupuk berbahan ubi jalar dan rumput laut memberikan pengaruh nyata pada aroma produk. Hasil uji Duncan diperoleh bahwa formula $A, B, C$, dan $D$ berbeda nyata. Faktor 
yang mempengaruhi aroma pada kerupuk yang dihasilkan yaitu daging ikan layang. Daging ikan layang mempunyai aroma yang kuat sehingga semakin tinggi fortifikasi daging ikan layang menyebabkan aroma kerupuk yang dihasilkan cenderung lebih kuat. Aroma kuat yang dihasilkan oleh kerupuk diduga berasal dari senyawa volatile yang ada pada ikan, senyawa volatile pada ikan diantaranya yaitu trimetil pirazin, tetrametil pirazin, benzaaldehida, fenil asetaldehida yang menyebabkan aroma kerupuk menjadi lebih kuat seiring dengan meningkatnya fortifikasi daging ikan layang.

\section{Kenampakan}

Histogram kenampakan kerupuk fortifikasi daging ikan layang dapat dilihat pada Gambar 3.

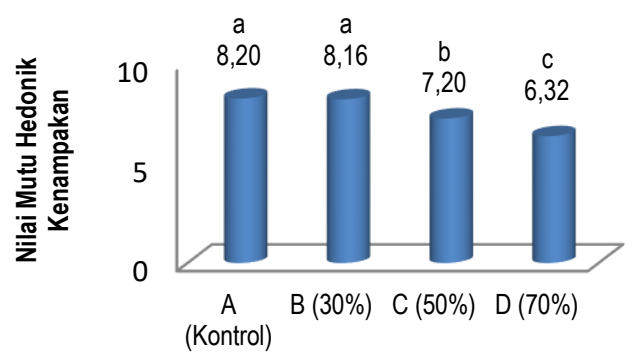

Gambar 3. Histogram kenampakan kerupuk. Huruf yang sama pada histogram menunjukkan hasil yang tidak berbeda nyata dan sebaliknya.

Gambar 3 menunjukkan nilai organoleptik mutu hedonik kenampakan kerupukberada pada kisaran $6.32-8.20$. Nilai mutu hedonik kenampakan tertinggi terdapat pada formula $\mathrm{A}$ (tanpa fortikfikasi daging ikan) yaitu 8.20 dengan kriteria utuh, rapi, bersih, homogen, ketebalan tidak rata, warna coklat. Sedangkan nilai mutu hedonik terendah terdapat pada formula D (fortifikasi daging ikan $70 \%$ ) yaitu http://ejurnal.ung.ac.id/index.php/jfpj/issue/archive
6.32 utuh, rapi, bersih, kurang homogen, ketebalan tidak rata, warna coklat. Kerupuk formula $B$ memiliki nilai mutu hedonik 8.16 dengan kriteria utuh, rapi, bersih, homogen, ketebalan tidak rata, warna coklat sertaformula C memiliki nilai mutu hedonik 7.20 dengan kriteria utuh, rapi, bersih, kurang homogen ketebalan kurang rata, warna coklat.

Hasil uji Krukal wallis menunjukkan bahwa penambahan daging ikan layang pada kerupuk berbahan ubi jalar dan rumput laut memberikan pengaruh nyata pada kenampakan produk (Lampiran 5). Hasil uji Duncan diperoleh bahwa formula A dan B tidak berbeda nyata namun berbeda nyata dengan formula $C$ dan $D$, sedangkan formula $C$ dan $D$ berbeda nyata.

Kenampakan kerupukdengan fortifikasi daging ikan layang yang berbeda menunjukkan kenampakan yang berbeda pula. Kenampakan kerupuk yang berbeda dipengaruhi oleh fortifikasi daging ikan layang yang berbeda. Semakin tinggi fortifikasi daging ikan layang nilai kenampakan semakin menurun, hal ini diduga karena meningkatnya kadar protein pada kerupuk yang dihasilkan. Kadar protein yang tinggi akan berpengaruh terhadap hasil kenampakan kerupuk, hal ini diduga karena adanya reaksi maillard yaitu reaksi antara protein dan gula pereduksi yang menyebabkan warna cokelat pada makanan. Pada reaksi ini, asam-asam amino terutama lisin berikatan 
dengan glukosa dan fruktosa membentuk produk akhir melanoidin.

\section{Rasa}

Histogram rasa kerupuk fortifikasi daging ikan layang dapat dilihat pada Gambar 4.

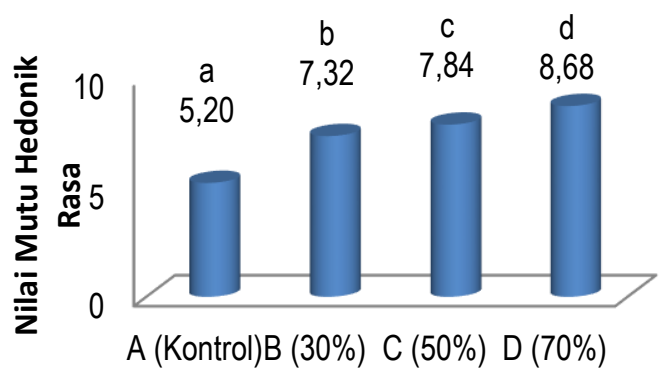

Gambar 14. Histogram rasa kerupuk. Huruf yang sama pada histogram menunjukkan hasil yang tidak berbeda nyata dan sebaliknya.

Gambar 4 menunjukkan nilai organoleptik mutu hedonik rasa kerupukberada pada kisaran 5.20 - 8.68. Nilai mutu hedonik rasa tertinggi terdapat pada formula $\mathrm{D}$ (fortifikasi daging ikan $70 \%$ ) yaitu 8.68 dengan kriteria rasa ikan cukup kuat. Sedangkan nilai mutu hedonik terendah terdapat pada formula A yaitu 5.20 (tanpa fortikfikasi daging ikan) dengan kriteria rasa ikan tidak ada. Kerupuk formula B memiliki nilai mutu hedonik 7.32 dengan kriteria ikan sedikit, serta formula $\mathrm{C}$ memiliki nilai mutu hedonik 7.84 dengan krtiteria rasa ikan kurang kuat.

Hasil uji Krukal wallis menunjukkan bahwa penambahan daging ikan layang pada kerupuk berbahan ubi jalar dan rumput laut memberikan pengaruh nyata pada rasa produk (Lampiran 5). Hasil uji Duncan diperoleh bahwa formula A, $B, C$ dan $D$ berbeda nyata.Rasa kerupuk yang berbeda disebabkan karena adanya pengaruh fortifikasidaging ikan layang yang berbeda. Semakin tinggi jumlah daging ikan layang yang

http://ejurnal.ung.ac.id/index.php/jfpj/issue/archive ditambahkan nilai mutu hedonik terhadap rasa semakin meningkat karena rasa dari daging ikan layang semakin kuat. Rasa kerupuk diduga berasal dari salah satu asam amino protein ikan yaitu asam glutamte yang dapat memberikan rasa lezat pada produk pangan. Rasa yang terdapat pada kerupuk juga dapat disebabkan oleh penambahan bumbu-bumbu dalam pembuatan kerupuk seperti bawang putih dan garam.

\section{SIMPULAN}

Hasil anlisis Bayes produk terpilih adalah fortifikasi daging ikan layang $70 \%$. Berdasarkan hasil karakteristik mutu hedonik kerupuk terpilih memiliki kriteria kenampakan utuh, rapi, bersih, kurang homogen, ketebalan tidak rata, warna coklat, rasa ikan cukup kuat, aroma ikan cukup kuat dan tekstur kering, agak getas.

\section{DAFTAR PUSTAKA}

Astawan, M., Koswara, S., Herdiani F. 2004. Pemanfaatan Rumput Laut (Eucheuma cottonii) Untuk Meningkatkan Kadar lodium dan Serat Pangan pada Selai Dan Dodol. Jurnal Teknologi Dan Industri Pangan. 15 (2): 61-69.

Badan Standardisasi Nasional. 1999. SNI 012713-1999. Kerupuk Ikan. Jakarta (ID): Badan Standardisasi Nasional

Dinas Kelautan dan Perikanan Provinsi Gorontalo. 2014. Data Statistik Produksi Perikanan Laut Provinsi Gorontalo. Gorontalo.

Ginting, S. 2010. Pemanaatan Ubi Jalar sebagai Bahan Pembuat Biskuit untuk Alternatif Makanan Tambahan Anak Sekolah Dasar di Desa Ujung Bawang Kecamatan Dolok Silau Kabupaten Simalungun, Skripsi Departemen Gizi 
Kesehatan Masyarakat Fakultas

Kesehatan Masyarakat. Universitas Sumatera Utara, Medan.

Pakaya, S. T. 2014. Karakteristik Kerupuk Berbahan Dasar Sagu (Metroxylon sp.) yang Disubtitusi dan DiFortifikasi dengan Rumput Laut (Kappaphycus alvarezii): [Skripsi]: Universitas Negeri Gorontalo

Winarno, F.G. 1990. Teknologi Pengolahan Rumput Laut. Pustaka Sinar Harapan. Jakarta.112 hlm.

Yulianingsih, L. 2005. Pengaruh Penambahan Karagenan Terhadap Karakteristik Fish Nugget dari ikan Mas [Skripsi]. Fakultas Perikanan dan IImu Kelautan. Institut Pertanian Bogor. 